\title{
Geography and Planning
}

$\mathrm{T}$ HE Geographical Association's annual conference usually has a theme corresponding to the interests of its president for the time being, and since in its choice of presidents the Association does not confine itself to academic geographers, considerable service to the subject is often done by this importation of a new viewpoint. This year the keynote of the Conference held at the London School of Economics on January 4-6 was the part that geography can play in planning. The presidential address, delivered by Prof. Patrick Abercrombie, professor of town planning at University College, London, was entitled "Geography, the Basis of Planning"; and a symposium on town and rural planning was the principal individual item in the programme. To a certain extent these items in the Conference may be considered as corollary to the important discussion on "Planning the Land of Britain", which was held at the Nottingham meeting of the British Association, as reported in NATURE of November 6, 1937, p. 791 .

Prof. Abercrombie took as his starting point the famous Geddes triad "place, work, folk" ; geography (place) represents the basis of planning, business (or work) the kernel of planning, and men and women (or folk) the purpose of planning. Planning may be defined as "any conscious effort to mould our environment for our own purposes". The geographer's aid to planning can be given by three types of study : the recording of natural conditions (geology, soil, vegetation, etc.), the tracing of the historic growth of adaptation to environment in the region, and, by combining these two, the presentation of a survey of existing conditions. A plea was put forward for the popularization of geology ; the Geological Survey provides ample material in the shape of maps and memoirs, but few people can interpret them without the aid of the professional geologist, and numerous fundamental errors have been made in planning which might have been prevented by a little elementary geological knowledge.

Dr. S. W. Wooldridge, however, in the symposium, contended that the matter is one for geographers; the geologist studies rocks mainly as a record of the earth's history, and is not primarily concerned with the form of the land, and its surface constitution. Both Prof. Abercrombie and Dr. Wooldridge pleaded for soil maps, but had little hope of their appearance for many years. But a more serious handicap is the absence of a complete drift map covering the whole country; the past and present geography of the drift-covered areas cannot be fully appreciated without a map showing the character of the surface deposits.

Dr. Wooldridge said, in addition, that for studying the form of the land something more than contour maps is necessary, and he deplored the abandonment of the fifth (Relief) edition of the Ordnance Survey One-Inch Map-a sentiment which was obviously shared by an audience consisting very largely of school-teachers. Another matter in which the planner must be interested is structure, especially in its effect on water supply. Dr. Wooldridge showed how sub-surface contour maps of water-bearing formations may be far more useful than simple cross-sections; for example, it may be demonstrated that the chalk is much nearer the surface underneath the central part of London than in the regions to the west and east, a fact which has an obvious bearing on the relative difficulty of securing water by boring. $\mathrm{He}$ cited cases, too, of buildings which had subsided through being built on a shallow clay formation overlying running sands, and mentioned that central London, built on. Thames terrace gravels, is the only part that has subsided appreciably, the parts built on London Clay showing no movement. He added a warning that the expansion of 'bungaloid growths' on the top of the chalk dip-slope around London may have disastrous effects on the pollution of the water, which runs down the dip to the areas from which well-water is obtained.

Both Prof. Abercrombie and Dr. Willatts were concerned with agriculture, which the former called the "Cinderella of planning". There is a well-known phrase "an army moves on its stomach"; it is equally true that the non-combatants must be fed in time of war, and in an island country such as Great Britain, it seems curious that so much attention should be given to the production of weapons of defence and aggression, and so little to the possibility of making the nation more self-supporting in essential foodstuffs. Agriculture, in the law, is not regarded as a development at all; 'development' consists of the utilization of the land for building purposes, and planning schemes plan the extension of urban areas, not the extension, nor even the retention, of agricultural land-use. The land, as Dr. Stamp said at Nottingham, is our one ultimate asset; the soil is a form of capital; yet not only have threequarters of a million acres of farm-land been lost to the nation since 1900 , but also, by a curious misfortune, it is usually the best agricultural land which is taken for building.

Dr. Willatts, who is organizing secretary of the Land Utilization Survey; stressed the need for a historical study of land utilization. The present use represents the result of centuries of adaptation; modern planning visualizes a sudden change. Only by studying the past land uses can apprisal be made of the optimum use of any given area. Thus near London there are three large areas of rich marketgarden land-actually amongst the finest soils in the country, in western Middlesex, south-west Essex and north-west Kent-all of which are being rapidly eaten into by the builder. No account whatever seems to have been taken of the agricultural value of this land, either in planned or haphazard development. It is noteworthy that London's open heaths (for example, Hampstead, Wimbledon) have remained as such for centuries because of poverty of soil ; they would make admirable residential areas, yet what an outcry there would be if they were to be built on! But thousands of acres of rich arable land, which for centuries has yielded abundant harvests to the farmer or small-holder, are now being destroyed by houses and factories without a protest being raised. The 'gravel subsoil' of the Thames terraces is far more valuable to the builder as an inducement to the prospective purchaser than the poorer clay land, and could far better be spared from 
the rapidly decreasing area of farm land. The question which the geographer, and the planner, may ask is, "Which is the best and most economic use of this land, considered from the national point of view-for houses or crops ?"

Lastly, Dr. R. A. Pelham urged a better appreciation of traditional building styles and materials in the development particularly of rural areas, in order that such "incongruous atrocities" as rows of red brick houses on the edge of Cotswold towns and villages might be avoided. It is feared, however, that this is an age in which utility and cheapness are more often considered than the rsthetic, and it is after all much cheaper and easier to build with mass-produced bricks than with elaborately prepared stone.
Apart from a highly entertaining and unbiased lantern lecture on South Russia and the Caucasus by Sir John Russell, and a fascinating biological intruduction to the study of landscape from Prof. H. H. Swinnerton, the remaining items in the Conference dealt mainly with educational subjects, ranging from the conception of geographical ideas by school-children to the conception of examination questions by examiners, and from the study of local geography by observation to the study of far-off lands by corresponding with the officers of 'tramp' ships. A lengthy report of a committee of the Association which has been studying world natural regions was also submitted and discussed; the report has been published in full in the December 1937 issue of Geography.
S. H. Beaver.

\section{Prize Awards for I937 of the Paris Academy of Sciences}

$\mathrm{A}^{\mathrm{T}}$ $\mathrm{T}$ the annual public meeting held on December 20 last the president announced the prizes and grants awarded in 1937 as follows :

Mathematics. The Francour Prize to Jean Leray, for his work on mathematical analysis.

Mechanics. The Montyon Prize to Lucien Malavard, for his electrical apparatus for the rapid calculation of the distribution of hydrodynamic circulations. The Poncelet Prize to Joseph Bethenod, for his work on mechanics and electricity. The Pierson-Perrin Prize to Léon Brillouin, for the whole of his work, especially for his contributions to the development of quantum mechanics.

Astronomy. The Lalande Prize to Michel Giaco. bini, for his work on stellar astronomy and comets. The Benjamin Valz Prize to Maurice Burgaud, for his work on terrestrial magnetism in China. The G. de Pontecoulant Prize to Henri Roure, for his work on planetary perturbations.

Geography. The Gay Prize to Jean Vignal, for his work on the accuracy of a method of levelling. The Tchihatchef Prize to Etienne Bruzon, for his travels, work and publications relating to the climate of Indo-China. The Binoux Prize to Raoul Goudey and Jean Lagrula, for their gravimetric observations made in France and Northern Africa. The Alexandre Givry Prize to Henri Legrand, for the whole of his hydrographical work in France and its colonies.

Navigation. The Plumey Prize to Roger Brard, for his studies on screw propellers.

Physics. The Kastner-Boursault Prize to Bernard Decaux, for his work on the applications of piezoelectric quartz to chronometry. The Gaston Planté Prize to Jean Bernamont, for his studies on the fluctuations of electrical resistances. The François Hébert Prize to Paul Couderc, for his work on astronomy. The Henri de Parville Prize to Paul Lainé, for his researches on the magnetic and magnetooptic properties of liquefied gases. The Hughes Prize to Paul Soleillet, for his work on the structure of light. The Clément-Félix Foundation to Etienne Vassy, for his work on atmospheric ozone.

Chemistry. The Montyon Prize (Unhealthy Trades) to Roger Renaud, for his work on gas masks. The Jecker Prize to Gustave Vavon, for his work on catalytic hydrogenation and the stereochemistry of the cyclic compounds. The Cahours Foundation to
Georges Laude, for his work on the synthesis of cyanic acid. The Paul Marguerite de la Charlonie Prize to Georges Darzens, for his work in organic chemistry. The Berthelot Prize to Jacques Parrod, for his researches on the synthesis of hydrocyanic acid. The Houzeau Prize to Marius Picon, for his work on sulphides and camphocarbonates. The Charles Adam Girard Foundation to Georges Brooks, for his researches in biological chemistry.

Mineralogy and Geology. The Delesse Prize to Mlle. Simonne Caillère, for her work on the minerals of the serpentine group. The Victor Raulin Prize to Mlle. Henriette Alimen, for her studies on the Stampian of the Paris basin.

Botany. The Desmazières Prize to Robert Potier de La Varde, for his work entitled "Mousses du Gabon". The Montagne Prize to Marius Chadefaud, for his work on Algæ. The Jean Thore Prize to Emile Chemin, for his biological researches on certain Algæ. The de la Fons Mélicocq Prize to Maurice Bouly de Lesdain, for his work entitled "Graminées indigènes et adventices des environs de Dunkerque". The de Coincy Prize to Raymond Benoist, for work in systematic botany in tropical regions.

Anatomy and Zoology. The Cuvier Prize to Paul Chabanaud, for the whole of his work. The Savigny Foundation to Henri Heim de Balsac, for his book on the mammals and birds of northern Africa.

Medicine and Surgery. Montyon Prizes to Emile Césari and Paul Boquet (2,500 franes), for their researches on the antigens of snake poisons and the antibodies of the sera; Michel Salmon (2,500 franos), for his book on the arteries of the skin; Jean Vague (2,500 franes), for his book "Les Hépatonephrites aiguës". Honorable Mentions (1,500 francs) to Ram Kumar Goyal, for his contribution to the study of the Streptothriceæ ; to Eugène Saint-Jacques, for his work on injections of animal charcoal in various diseases; and to Jean Terracol, for his book on the diseases of the nasal fossa. The Barbier Prize to P. Emile Weil, Paul Isch Wall and Mme. Suzanne Perlès, for their book on the puncture of the spleen. The Bréant Prize to Georges Girard and Jean Robic, for their work on the application to man of a new vaccine against plague. The Godard Prize to Gaston Gros, for his memoir on sexual endocrinology. The Mège Prize to Georges Curasson, for his treatise on 